NBER WORKING PAPER SERIES

\title{
PRODUCT QUALITY AND \\ WORKER QUALITY
}

John M. Abowd

Francis Kramarz

Antoine Moreau

Working Paper No. 5077

\author{
NATIONAL BUREAU OF ECONOMIC RESEARCH \\ 1050 Massachusetts Avenue \\ Cambridge, MA 02138 \\ April 1995
}

We would like to thank participants of the NBER Labor Studies Group Summer Institute (July 1994), the C.V. Starr Conference at NYU (December 1994), and the ADRES Conference (December 1994) for helpful comments. In particular, comments from S. Berry, B. Jovanovic and A. Pakes were especially useful. Of course, all errors remain ours. Abowd acknowledges financial support from the National Science Foundation (grants SBR 91-11186 and SBR 9321053). The data used in this study are confidential but the authors' access is not exclusive. Other researchers interested in using these data should contact CREST, ENSAE, 15 bd Gabriel Péri, 92244 Malakoff Cedex, France. This paper is part of NBER's research program in Labor Studies. Any opinions expressed are those of the authors and not those of the National Bureau of Economic Research.

(C) 1995 by John M. Abowd, Francis Kramarz and Antoine Moreau. All rights reserved. Short sections of text, not to exceed two paragraphs, may be quoted without explicit permission provided that full credit, including $\odot$ notice, is given to the source. 
NBER Working Paper \#5077

April 1995

\title{
PRODUCT QUALITY AND \\ WORKER QUALITY
}

\begin{abstract}
We study the relation between product quality and worker quality using an economic model that, under certain conditions, provides a direct link between product price, product quality and work force quality. Our measures of product quality are the evolution in the detailed product price relative to its product group and the level of the product price relative to this group. Our worker quality measures are the firm's average person effect and personal characteristics effect from individual wage rates. We find a very weak, generally positive, relation between worker quality and product quality using detailed firm-level data from the French Producer Price Index surveys.
\end{abstract}

John M. Abowd

School of Industrial and Labor Relations

Cornell University Ithaca, NY 14853-3901

and NBER
Francis Kramarz

CREST/INSEE

Département de la Recherche

15, bd Gabriel Péri

92244 Malakoff Cedex

FRANCE

\author{
Antoine Moreau \\ CREST/INSEE \\ Département de la Recherche \\ 15, bd Gabriel Péri \\ 92244 Malakoff Cedex \\ FRANCE
}




\section{Introduction}

This paper investigates the link between the quality of a firm's products and the quality of its work force. Product quality, although difficult to measure across diverse industries, is related to the purchasers' willingness to pay more for a good that is, in all other measured dimensions, the same as a less-expensive alternative. Worker quality, equally difficult to measure, is related to the employers' willingness to pay more for a worker who is, according to all measurable characteristics, identical to many other workers. Although the economic theory linking product and worker quality is relatively new, we present one model, in the spirit of Kremer (1993), which suggests that, under perfect competition, worker quality and product quality will be positively related but that, under imperfect competition, the relation is ambiguous. As in Kremer's model, our model implies a direct relation between product quality and product price, thus, providing a rationale for the direct use of product price as the quality measure. ${ }^{1}$ As an example, consider the emerging notion of a "high-performance work place" where the firm's work force must acquire high skill levels, develop self-managing teams, and improve product quality continuously. The high-performance work place is driven by the belief that this production technology makes the best use of the high quality employees for producing high quality products. In service industries, where customer contact is an essential feature of many jobs, a high quality work force changes the nature of these contacts and, by itself, could improve the quality of the product. To be sure, empirical evidence is scarce since the data requirements are so stringent (however, see Doms, Dunne and Troske (1994)).

We equate a product's quality with its market price. In a perfectly competitive product market product price is monotonically positively related to product quality and worker quality among highlystandardized goods, so that, within these standardized product categories, relative price variation measures quality differences. As a

\footnotetext{
${ }^{1}$ Stokey (1990) considers a much more complex model of the relation between worker quality and product quality using characteristic of the good to construct a theoretical index of product quality. Eymard-Duvernay (1993) and Letablier and Delfosse (1994) consider the relation between product quality, as measured by standardized labelling requirements (appellation d'origine contrôlée) and worker quality.
} 
practical example, consider two window cleaner products-one with ammonia and one with lemon juice. These are considered to be two distinct basic products. Among the window cleaners with ammonia there are several versions, called elementary products in our analysis. The higher priced window cleaner with ammonia is hypothesized to be a higher quality product than the lower priced window cleaner with ammonia. Indeed, we go somewhat further. Suppose that both window cleaners with ammonia began the period with the same price but one finished the period with a higher price; then, we assert that the product with the larger price increase is of higher quality.

In the labor market, the equation of worker quality with price means that measured and unmeasured person characteristics in the wage rate equation capture the heterogeneity in worker quality. Hence, when we measure wage rates for the same worker in jobs at a variety of employers and characteristics of this worker at several points in time, we assert that a worker with a larger person effect (wage rate component that is common to all employers but not captured by measured characteristics) is a higher-quality worker. So, we use the average person effect within a firm as a measure of unobserved (by the econometrician) worker quality and the average predicted wage given worker characteristics as a measure of observed worker quality.

The central question, then, is whether or not these two pricebased measures of worker and product quality are positively related. According to our theoretical model, these two measures should be positively related under perfect competition but might not be so related under imperfect competition.

Section 2 presents our model relating worker quality to product quality. Section 3 describes the product quality measures we constructed. Section 4 describes our measures of worker quality. Sections 5 and 6 present the empirical results. Section 7 concludes.

\section{Worker Quality and Product Quality: a Model}

We require a theoretical model that relates differences in worker quality to differences in detailed product price, given a basic prod- 
uct group. Within a basic product group, each detailed product is unique. Hence, it seems reasonable to allow imperfect substitutability among these products. In addition, each firm is heterogeneous with respect to the technology it can use to produce the detailed products. We model this heterogeneity as a difference in the complexity of the production process. Thus, higher quality products are produced using a more complex technology.

We extend Kremer's (1993) model of equilibrium choice of technology (p. 561-563) to allow for imperfect substitutability between elementary products within a given basic product group. In Kremer's model, workers are endowed with a quality $q$ corresponding to the probability that the worker can perfectly execute a given essential task in the production process. Hence, with probability $1-q$ the task is performed improperly and the resulting product is worthless. Product quality is, thus, related to the production process complexity. There is a continuum of workers following some exogenous distribution of worker quality $\phi(q)$. Labor is supplied inelastically. There are $n$ tasks to perform. The firm selects among technologies with different $n$. All tasks require the same amount of labor. $B(n)$ is the value of output per tasks if all tasks are performed perfectly $\left(B^{\prime}(0)>0\right.$ and $\left.B^{\prime \prime}(n)<0\right)$. An increasing $n$ means increasing complexity since there are more possibilities for mistakes.

As in Kremer's model, firms make zero-profit due to potential entry. However, unlike his approach, we consider both the perfect competition case, where firms are price-takers, and an extension the model to the case of imperfect competition with an inverse demand function (see Tirole (1989) p. 298-299):

$$
Q_{j}=k P_{j}^{-\frac{1}{1-\rho}} k>0
$$

where $Q_{j}$ is firm $j$ production. The demand elasticity for product $j$ is approximately:

$$
\varepsilon=\frac{1}{1-\rho}
$$

where $0<\rho \leq 1$ (see Tirole). Hence,

$$
p_{j}=K Q_{j}^{\rho-1}
$$


The profit function becomes

$$
\Pi_{j}=p_{j} \Pi_{i=1}^{n_{j}} q_{i} n_{j} B\left(n_{j}\right)-\sum_{i=1}^{n_{j}} w\left(q_{i}\right)
$$

where $\Pi_{i=1}^{n_{j}} q_{i} n_{j} B\left(n_{j}\right)$ is the production function for $Q_{j}$ given the probability structure described above.

Each firm maximizes $\Pi$ with respect to $n_{j}$ and in $q_{i}, i=1, \ldots, n_{j}$. The only difference between our equation (2) and Kremer's (11) is the presence of a price $p_{j}$ here, whereas Kremer's price is normalized to 1 and is the same for all firms. Using Kremer's results, we know that potential equilibria have the property that allocations of workers to firms occur such that workers of the same skill, say $\left(q_{j}\right)$, are employed by the same firm. So, equations (1) and (2) yield:

$$
\Pi_{j}=K q_{j}^{n_{j} \rho} n_{j}^{\rho} B^{\rho}\left(n_{j}\right)-n_{j} w\left(q_{j}\right)
$$

to maximize in $n_{j}$ and $q_{j}$. The first-order conditions together with the zero-profit condition give:

$$
\frac{d w}{d q_{j}}=K \rho n_{j}^{\rho} B^{\rho}\left(n_{j}\right) q_{j}^{n, \rho-1}
$$

and, by integration,, we have:

$$
w\left(q_{j}\right)=K n_{j}^{\rho-1} B^{\rho}\left(n_{j}\right) q_{j}^{n_{j} \rho}+c
$$

and $c=0$ because of the zero-profit condition (see also Kremer). ${ }^{2}$ Hence,

$$
w\left(q_{j}\right)=K n_{j}^{\rho-1} B^{\rho}\left(n_{j}\right) q_{j}^{n_{j} \rho}
$$

In equation (3) note that $K=1$ and $\rho=1$ (the perfect substitution case) yield equation (12) in Kremer (1993). The first-order condition in $n_{j}$ yields:

$$
\rho \log q_{j} n_{j}+\rho+n_{j} \rho \frac{B^{\prime}\left(n_{j}\right)}{B\left(n_{j}\right)}=1
$$

or

$$
-\log q_{j}=\frac{\rho-1}{\rho n_{j}}+\frac{B^{\prime}\left(n_{j}\right)}{B\left(n_{j}\right)}
$$

There are two possible regimes. Kremer considers the case where $\rho=1$ to get his equation (14) which yields the following prediction:

\footnotetext{
${ }^{2}$ If capital costs are also heterogeneous, then the zero profit condition must be modified to reflect this heterogeneity.
} 
"The left-hand side declines monotonically in $q_{j}$. Since $B^{\prime}(0)>0$ and $B^{\prime \prime}\left(n_{j}\right)<0$, the right-hand side declines monotonically in $n_{j}$ as long as $B^{\prime}\left(n_{j}\right)>0$. Therefore, $n_{j}$ is an implicit function of $q_{j}$ with $n_{j}^{\prime}\left(q_{j}\right)>0$."

In words, more complex products or techniques (high $n_{j}$ ) require high $q_{j}$ workers. The cases $\rho>1$ and $\rho<0$ would reproduce Kremer's argument but are inconsistent with quasi-concavity of the consumer's utility function and profit-maximization under imperfect competition, respectively. Finally, contrary to Kremer's result, whenever $0<\rho<1$, i.e. whenever product competition is not perfect, the relation between $n_{j}$ and $q_{j}$ may have different shapes: complex products and high quality workers are no longer always positively related. Furthermore, contrary to the perfect competition case $(\rho=1)$, by the same argument, high prices are not systematically associated with better quality products since, at the equilibrium

$$
p_{j}=\frac{1}{K}\left[q_{j}^{n_{j}} B_{j}\left(n_{j}\right) n_{j}\right]^{1-\rho}
$$

Thus, the relation between product quality (as reflected in the price) and worker quality need not be positive under imperfect competition. Furthermore, even if we find a positive relation between our product quality measures and our worker quality measures, imperfect competition (imperfect substitutability between elementary products) may explain weak rather than a strong association between the two measures. This empirical relation is investigated in the following sections.

\section{Price-based measures of product quality}

Our measure of a product's quality is based upon a detailed firmlevel survey of transaction prices for elementary products (approximately equivalent to U.S. 8-digit commodity class codes) within basic product groups (approximately equivalent to U.S. 6-digit commodity class codes). In terms of the theoretical model above, the elementary products within a single basic product group are (possibly) imperfect substitutes with a common product elasticity of demand $\varepsilon$. 
Because the French Producer Price Index survey program is unique and not well-known (even in France) our Data Appendix includes a detailed description of the survey methodology as well as our methods for constructing the product quality variables (for a remarkable analysis in the US, see Gordon (1990)). The data were collected as a part of the Producer Price Index program. They are collected for manufacturing firms with a primary focus on intermediate goods. We use data from the period 1978 to 1988 , in order to maximize the correspondence with the other firm and individual data sets we have constructed from INSEE sources.

Table 1 shows the number of firms, basic products (6-digit classification), and elementary products (8-digit classification) for each of the 162 -digit industrial groups that we were able to study. The restriction to manufacturing firms, the sampling frame of our representative enterprise sample (see Corbel 1989), and the sampling frame of the French PPI program (which emphasizes larger firms) interact to yield a sample of 748 usable firms producing 4,791 elementary products in 948 basic product groups. By design, it is not possible to distinguish elementary products and firms. A firm may produce several elementary products but no two firms produce the same elementary product.

Table 2 provides summary statistics for the distribution of elementary products among the firms in each of the 162 -digit industry groups. Table 3 shows the distribution of elementary products per basic product for the same 16 industry groups. Notice that the minimum number of elementary products per basic product is two, a restriction that we imposed on the analysis. ${ }^{3}$

To construct the Producer Price Indices, INSEE measures elementary product prices within the same basic commodity class (6-digit basic commodity groups composed of 8-digit elementary products). Appendix B contains a table of examples of basic and elementary products taken directly from the French PPI program. The elementary products in each basic product group are displayed for four different firms (two basic chemical and two textile) for four chemical basic products and two textile basic products. Figure 1

\footnotetext{
${ }^{3}$ Since we control for the basic product in all our regression, basic product groups with a unique elementary product would be useless.
} 
illustrates the quarterly history of the elementary price indices for four firms in a particular basic commodity group in the chemical industry (at this level of detail the names of the basic and elementary products are confidential). For this basic product group the elementary prices move together. There is almost no dispersion in the relative prices of the elementary products. Notice, however, that the data are cyclically variable, indicating that the elementary product prices reflect market conditions as transaction prices (but not list prices) would. Figure 2 shows the elementary product price indices for another basic chemical product. Here, there is more relative price dispersion among the elementary products but, again, the elementary price indices move together and are cyclically sensitive. Finally, Figure 3 shows four elementary products in a basic textile product group. Here, there is considerable relative price dispersion with cyclical components that are similar.

We use two statistics based upon the elementary product prices as dependent variables in our analysis. The first of these is the within year rate of growth of the elementary good price relative to the growth rate of its basic commodity group. We call this variable the Price Evolution Index. To compute this index we begin with an index of prices, $B_{b, t}$, within each basic commodity group $b$, that is a weighted average of the elementary prices, $p_{e, t}$, for all elementary products $e$ in basic product group $b$. This index of basic prices is normalized to one at the beginning of each year. The elementary product prices are measured monthly or quarterly over the year. At any time $t+h$ the index of basic commodity prices is $B_{b, t+h}$ and our measure of relative price increase for an elementary commodity, $e$, is:

$$
I_{e, t+h}=\frac{\left(p_{e, t+h} / B_{b, t+h}\right)}{\left(p_{e, t} / B_{b, t}\right)}
$$

where $p_{e, t}$ denotes the price of an elementary product $e$ at date $t$. Therefore, the relative price of an elementary product rises during the year if, and only if, its price rises more than the average rise of the elementary products in its basic product group. Within each year $(h<1)$ the index of basic prices changes as the component elementary product prices change. At the end of each year $(h=1)$, the index $B_{b, t+1}$, based on the elementary products in the index $B_{b, t}$, 
is used to compute $I_{e, t+1}$, which represents the relative price variation for one year for a particular elementary product. Then, new elementary products and new firms are allowed into the basic product group and the index $B_{b, t+1}$ is renormalized to one using weights appropriate for the year $t+1$. Our measure of average relative price variation (the Price Evolution Index) for a given elementary product is the average of $I_{e, t}$ for all the years from 1978 to 1988 for which the elementary product was sampled.

Table 4 provides summary statistics for the Price Evolution Index for each industry group. Notice that the median is always within 0.02 of 1.00 , even though it is the average and not the median that is normalized to one. The dispersion (interquartile range) of our Price Evolution Index is small but certain industries have large ranges indicating that there are some elementary products with substantial within year price variation.

We also calculate a relative price level index (called the Relative Price Level) for each elementary product in our sample. This index is not an official INSEE PPI statistic. For each basic product group, $b$, let the simple average of the elementary product price within the group at date $t$ be $P_{b, t}$. Then, our relative price index is:

$$
R_{e, t}=\frac{p_{e, t}}{P_{b, t}}
$$

For all elementary products in the same basic product group, the average value of $R_{e, t}$ is one every year. However, any particular product may experience relative price changes continuously over the sample period. Consequently, the dispersion of the Relative Price Level $R_{e, t}$ is much larger than the dispersion in the Price Evolution Index $I_{e, t}$. (See Table 5.)

\section{Wage-based measures of worker quality}

Our measures of worker quality and firm-level compensation policy were taken from Abowd, Kramarz and Margolis (1994). In that paper, Abowd et al. decomposed annual real total compensation $y_{i t}$ for individual $i$ in year $t$ employed at firm $J(i, t)$ into the following components:

$$
y_{i t}=\mu+x_{i t} \beta+\alpha_{i}+u_{i} \eta+\phi_{J(i, t)}+\gamma_{1 J(i, t)} s_{i t J(i, t)}+\gamma_{2 J(i, t)} T\left(s_{i t J(i, t)}-10\right)+\varepsilon_{i t}
$$


where

$$
\mu \equiv \text { the grand mean of } y_{i t}
$$

$x_{i t} \beta \equiv$ the component due to measurable characteristics $x_{i t}$

$\alpha_{i} \equiv$ the unobservable (to the econometrician) component

$u_{i} \eta \equiv$ the component due to non-time-varying observables $u_{i}$

$$
\phi_{J(i, t)}+\gamma_{1 J(i, t)} s_{i t J(i, t)}+\gamma_{2 J(i, t)} T\left(s_{i t J(i, t)}-10\right)
$$

$\equiv$ the firm-specific component of the compensation policy

with

$$
\begin{gathered}
s_{i t J(i, t)} \equiv \text { firm-specific seniority } \\
T(.) \equiv \text { the first order spline basis function }
\end{gathered}
$$

and

$$
\varepsilon_{i t} \equiv \text { the statistical error term. }
$$

They estimated this model using a dataset with more than $1,000,000$ workers from 500,000 firms who were followed from firm to firm over the period 1976 to 1987 . They computed a wage-based measure of the unobserved quality of each worker from the average of $\alpha_{i}$ within each firm $\left(\equiv \alpha_{j}\right)$ and of the observable quality differences related to time-varying observables from the average of $x_{i t} \beta\left(\equiv x_{j} \beta\right)$ and education (non time-varying) from the average of $u_{i} \eta\left(\equiv u_{j} \eta\right){ }^{4}$ These measures of worker quality and the estimated measures of firm-specific compensation policy $\left(\phi_{j}, \gamma_{1 j}\right.$, and $\left.\gamma_{2 j}\right)$ were merged into a sample of 16,913 industrial and service firms. The firms were taken from a dynamically representative (unbalanced) sample of the French private and government-owned firms (Corbel 1989) for which detailed accounting and employment structure data were available (Abowd, Crepon, Kramarz and Trognon, 1994).

Table 5 shows summary statistics for all variables for all firms in our elementary product sample. The unit of observation is a firm. Compensation variables are shown in the top panel. Price evolutions and levels are shown in the middle panel. Summary statistics on firm outcomes (levels and growth rates) and employment structure are shown in the bottom panel.

\footnotetext{
"All regression parameters ( $\beta$ and $\eta$ ) in the Abowd, Kramarz and Margolis model were estimated separately for men and women.
} 


\section{Results}

Table 6 shows the results of a regression analysis using the Price Evolution Index as our measure of product quality. Columns (1) and (2) were calculated for all 4,791 elementary products, with a complete set of 6-digit basic product indicators included. ${ }^{5}$ Consider the results given in column (2). The compensation variables are related to product price evolution; however, these relations are not strong. the firm-level employment structure variables are strongly related to product price evolution. Two measures of worker quality are positively related to product quality-the average effect of time-varying observables $(x \beta)$ and the average individual effect $(\alpha)$. However, the ratio of Engineers, Technicians and Managers to total employment and the ratio of skilled workers to total employment are not significantly related to price evolution. Surprisingly, one measure of worker quality is negatively related to product quality-average education effect $(u \eta)$. A one standard deviation increase in all of these variables changes predicted product quality by approximately $1 \%$. The firm-specific compensation intercept $(\phi)$ as well as the seniority reward $\left(\gamma_{1}\right)$ are negatively related to product quality with an effect on the same order of magnitude as the ones above. Finally, none of our growth variables (employment, sales or assets) is related to the price evolution product quality measure.

We have interpreted these results assuming that our product price evolution index is good proxy for product quality; however, we recognize that several other interpretations are plausible. First, increases in the relative price of one elementary product as compared to the other elementary products in its basic product group could also be related to a firm's market position vis-à-vis other competitors in markets with imperfect competition. For example, one explanation for the effect of $\phi$ on relative price evolution is that firms with some market power split the quasi-rent from this position with the employees. Prices and wages are both higher at the beginning of the period (when the index is normalized). Over the course of the pe-

\footnotetext{
${ }^{5}$ In a first version of this paper, mono-product firms were also analyzed. These firms were defined as having elementary products in a single basic product group. The results were difficult to interpret. In particular, even if such firms are included by the PPI program within a unique basic product group, they may still produce products in other groups. They only differ from other firms in that these indices were not collected by INSEE.
} 
riod, there is a tendency for the relative price of these elementary products to fall, due to the effects of increased competition owing to the initially higher prices. Hence, this effect need not be related to a deterioration of the product's quality. Second, it must be noted that we do not control for the evolution in quantities of each elementary product produced by each firm. This information is not currently available. ${ }^{6}$ We approximate this evolution by using the growth rate of total sales within the firm (in value), as well as growth rates of employment and assets, over the period. These aggregate measures do not appear to have any relation to the price evolution index.

In Table 7 we show the results for a regression analysis of our relative price level measure of product quality. In Column (2) we find that relative price levels are slightly higher for elementary products with higher education effects $(u \eta)$ or higher observables effects $(x \beta)$, and much higher for firms with higher skill structures (Engineers, etc. and skilled workers per employee). Unobserved worker quality is not important in this regression. This pattern of results seems much closer to cost function estimates than the type of product quality differences we were trying to measure. Finally, note that our price level ratio is higher for firms where $\gamma_{2}$, the spline after ten years of the returns to seniority, is larger. If our price level measures complexity of the product, this association may reflect the importance of learning in firms with high prices: workers stay in the firm because of deferred compensation. ${ }^{7}$

With respect to equation (5), which relates the price to the average worker quality, and equation (4), which relates the optimal quality to the degree of production complexity, the estimated relations in Tables 6 and 7 suggest only a very weak link between price and worker quality, as measured by our wage equation components. Table 7 does, however, suggest a rather strong relation between worker skill level, as measured by the skill categories we used, and the product price. Thus the relation between production complexity (assumed to be reflected in the product price) and measured worker

\footnotetext{
${ }^{6}$ Thus, we cannot apply the methods in Berry, Levinsohn and Pakes (forthcoming).

${ }^{7}$ There is no theoretical reason to distinguish between the effects of time-varying individual characteristics $x \beta$ and non time-varying individual characteristics $u \eta$ in the models in Tables 6 and 7 . We estimated the two basic equations including the sum $x \beta+u \eta$. For the price evolution index the effects cancel and the coefficient is zero. For the relative price level the effect is 0.70 ( \pm 0.27$)$, which is essentially the average of the two coefficients in Table 7 .
} 
skill level receives some empirical support.

\section{Further Investigation Using Matched Indi- vidual Firm Data}

Our measures of product quality in the previous sections were indirect. However, in 1987 the supplement to the French Labor Force Survey, focused on new technologies and work place organization. Among a wealth of other variables, there is a direct question about existence of quality norms within the firm. Hence, it is possible to examine directly relation between individual wages and quality norms, controlling for many individual and firm characteristics. Using variable definitions from Entorf and Kramarz (1994), individuallevel characteristics include the use of new technologies (NT henceforth), experience with NT, and all of the usual variables present in wage equations. As for firm-level variables, besides industry and size of the employing firm, we know the asset level, the rate of profit (operating income divided by total assets), the skill structure of employment and the rate of export. Using these variables, as well as the direct question on quality norms, we estimated the regression equation whose results are shown in Table 8 . The coefficient on the quality norm variable is positive (0.013) and marginally significant. Hence, this evidence also supports the notion of a small positive relation between worker quality and product quality.

\section{Conclusion}

We were looking for a relation between product quality and worker quality. Building on Kremer (1993), we proposed a model in which elementary products are imperfect substitutes within a basic product group. Our model shows that the investigated relation may be weak. In our empirical analysis, our proxies for product quality were based upon relative price movements and relative price levels for elementary products at an extremely detailed level (approximately 8digit) controlling for basic products at a very detailed level (approximately 6 -digit). Consequently, we believe that the technological 
differences among our firms, given their basic products, are minuscule. A priori, there are good reasons to believe that within-year product price variation, controlling for basic product group, represents changes in product quality. The case is less strong for the relative price levels. We do find some positive relations among our firm-level worker quality variables and price evolutions; however, we also find some negative relations. In addition to our product quality interpretation, we also offer some additional explanations, which require some non-competitive structure in the product market. If product quality and worker quality are positively related, the effect is apparently more important for sorting workers among diverse and nonsubstitutable products than for explaining variation within groups of imperfectly substitutable detailed products. 


\section{References}

Abowd J., Crépon B., Kramarz F. and A. Trognon (1994), "A la Recherche des Moments Perdus: Covariance Models for Unbalanced Panels with Endogenous Death," INSEE working paper.

Abowd J., Kramarz F. and D. Margolis (1994), "High-Wage Workers and High-Wage Firms," NBER working paper, 4917.

Berry, S., Levinsohn, J. and A. Pakes (forthcoming) "Automobile Prices in Market Equilibrium," Econometrica.

Corbel P. (1989), "Echantillon d'Entreprises éétat d'avancement," INSEE, note 13/G231.

Doms M., Dunne T. and K. Troske (1994), "Workers, Wages and Technology," U.S. Census Bureau (CES) working paper.

Entorf H. and F. Kramarz (1994), "The Impact of New Technologies on Wages: lessons from matching panels on workers and on their firms," INSEE working paper.

Eymard-Duvernay, F. (1994) "L'Entreprise comme dispositif de coordination: Modèles d'entreprises, qualifications du produit, qualifications du travail," Centre d'études de l'emploi working paper.

Gordon R. (1990), The Measurement of Durable Good Prices, NBER Monograph Series, University of Chicago Press.

Kremer M. (1993), "The O-Ring Theory of Economic Development," Quarterly Journal of Economics, Vol. CVIII, 551-575.

Letablier M. and C. Delfosse (1994) "Qualité des produits et qualification des territoires," La Lettre, Centre d'études de l'emploi, 1-11.

Stokey, N. (1990) "Human Capital, Product Quality and Growth," NBER working paper no. 3413. 


\section{Appendix: Construction of the Price Data}

The prices we uses to compute our quality indicators were collected by INSEE to compute the Producer Price Indices (PPIs). First, we describe how these prices were collected. Second, we discuss the methods used to compute the variables used in our analyses. Finally, we provide some additional descriptive statistics concerning these price measures.

\section{The French PPI program}

The collection of transaction prices to compute PPIs began at the end of the 1970's in France. Earlier surveys (Wholesale Price Indices) measured only list prices (i.e., without discounts) were. The transaction price surveys began with important intermediate products as determined by their shares in the PPI. Gradually, all intermediate products and some final products were introduced. Currently there are over 10,000 basic products covered by the PPI program. Our study is limited to the selected industry groups whose prices were followed for the PPIs during the period 1978 to 1988 .

The collection of prices for a given industry (NAP 600, 4-digit SIC) begins with a size-based sample of the firms in which the largest firms in the industry group are sampled until 60 to $80 \%$ of total industry group sales are covered by the sampled firms. This coverage may be lower in less concentrated industries. The firms participating in the index are thus the largest French firms in their 4-digit industry.

Once the firms have been chosen, a field agent is sent to each one. The field agents, contractual INSEE employees, working for the PPI program are former engineers with extensive private sector experience in the relevant industry. In general these engineers are 50-55 years old when they begin to work in the PPI program at INSEE.

The purpose of the field agent's visit to the firm is to design the questionnaire, unique to each sampled firm, which will be used for the five year survey period. The field agent must analyze the way the firm sets its prices (distribution channels, types of discount, etc.) and how these prices are recorded in the firm's accounts. The goal is to collect true transaction prices from the sellers; therefore, confidentiality is essential. To ensure that the firm will give INSEE the 
required information, the field agent is told to base the questionnaire on information that can be directly retrieved from the company's records. In general, firms use management information systems that offer easy access to prices billed at the delivery (invoice prices). On the other hand, true order prices (i.e. including discounts that extend over multiple orders) are rarely recorded. Thus, the collected prices are mostly invoice prices, and in a few cases, order prices. For many intermediate goods, there is not much difference between these two prices. The direct contact with the sampled firms and the customization of the questionnaire is crucial for the quality of the survey. The results obtained when INSEE tried to collect the necessary information by mail were far less satisfactory.

The next task of the field agent is to choose "elementary products", 8-digit products unique to the firm whose transaction prices will be collected for the computation of the PPIs. As in the choice of firms, there is not random sampling of elementary products. Choosing the elementary products requires disaggregation of the firm sales into homogeneous "basic product" groups (6-digit classification). The main products of each basic product group are sampled. A basic product group is homogeneous if, in the opinion of the field agent engineer, the price variation among the products it covers is similar and the products themselves are very close production substitutes. Choosing elementary products is a very difficult task. Even the technical employees within the firm have difficulty in determining homogeneous basic product groups. The INSEE field agents in the PPI program base their decisions upon the firm's information and their industrial experience. Thus, it is certainly possible that basic products do not correspond exactly to a homogeneous market, but it should be stressed that they correspond to at least the 6 -digit level of product codes used in the American PPI..

An elementary product is not only defined by its technical characteristics. However, INSEE is trying to measure pure price changes. Hence, changes in the reported prices of elementary products should correspond to some change in the firm's pricing decisions and not to other aspects of its business operations. Thus if, for example, price levels are different between two different distribution channels, the field agent should ask the firm to give the price for one channel. 
Therefore, the definition of an elementary product also includes the characteristics of the transaction: type, of the typical customer, of the guarantee, of the packaging, and so forth. Unfortunately, this complexity of definition often conflicts with the goal of collecting true transaction prices, because firms, in general, cannot easily tell which amount they charge at such a disaggregated level. It is, therefore, possible that some observed price changes are due to changes in some of the transaction characteristics.

The number of elementary products followed in each firm depends upon various factors: size of the firm, number of basic products, and number of elementary products in each basic group. It also depends upon the firm's degree of cooperation in the survey. On average there were four elementary products per firm in 1988.

Finally, the field agent has to collect sales corresponding to each basic product, which are used to weight the basic indices $\left(B_{b t}\right)$ in the general PPI. Prices and sales are calculated for the domestic market with exports excluded.

The customized questionnaire is sent to the firm on a monthly or quarterly basis. The staff of the PPI program at INSEE monitor the survey response and telephone the respondent firm when there are irregularities in the responses. Firms are asked to report changes in the elementary and/or basic products directly to the INSEE field agent. In practice, changes in products are mainly detected through abnormal price variations detected in the questionnaire responses and investigated by the PPI staff. If there is a significant change in the quality of an elementary product, inducing a significant change in its price, then a new elementary product is created.

There are two ways of introducing new products into the index. Every five years the indices of certain industry groups are rebased. At that time the firms are resampled, new basic products and new elementary products are defined and the questionnaires are redone. Different industry groups may have different base years as it is impossible to rebase all sectors in a given year.

The second way of introducing new products into the index is when an elementary product chosen during the previous rebasement is not marketed anymore. Firms are asked, in this case, to give INSEE the price of a close substitute product and the two are linked 
in the index using price and cost information from the firm.

Finally, we note that technical characteristics of the products, which might be used to measure their quality, are not recorded in sufficient detail.

Construction of the firm-level dataset

The data containing the individual indices computed for the PPI were merged with the dataset used in Abowd et al (1994) using the SIREN, which allows one to identify the firm in both datasets. Of the 4,248 different SIREN in the master PPI dataset 748 remain after the merge. Both datasets oversample large firms, which, therefore, survive the merge process with a much greater probability than smaller or intermediate size firms. 
Table 1

Summary Statistics for Firms

Number of Firms, of Elementary Products and of Basic Products

\begin{tabular}{|c|c|c|c|}
\hline & $\begin{array}{c}\text { Firms } \\
\text { (number) }\end{array}$ & $\begin{array}{c}\text { Elementary Products } \\
\text { (number) }\end{array}$ & $\begin{array}{l}\text { Basic Products } \\
\text { (number) }\end{array}$ \\
\hline \multicolumn{4}{|l|}{ Intermediate Goods } \\
\hline Refined Petroleum Products & 7 & 94 & 16 \\
\hline Basic Steel Products & 13 & 44 & 12 \\
\hline Non Ferrous Metals & 5 & 16 & 5 \\
\hline Construction Materials & 60 & 255 & 52 \\
\hline Glass Industry & 16 & 57 & 14 \\
\hline Basic Chemicals & 45 & 250 & 67 \\
\hline Metallic Products & 34 & 183 & 36 \\
\hline Paper Industry & 59 & 193 & 34 \\
\hline Plastic and Rubber Industry & 76 & 385 & 68 \\
\hline \multicolumn{4}{|l|}{ Equipment Goods } \\
\hline Machinery Construction & 184 & 1445 & 293 \\
\hline Electrical Equipment & 56 & 450 & 78 \\
\hline Automobile Industry & 4 & 12 & 4 \\
\hline \multicolumn{4}{|l|}{ Consumption Goods } \\
\hline Parachemicals & 58 & 451 & 96 \\
\hline Textile and Clothing & 78 & 377 & 77 \\
\hline Wood and Furnishing & 78 & 579 & 96 \\
\hline Total Number & $773^{*}$ & $4 \overline{491}$ & 948 \\
\hline
\end{tabular}

Notes : For sources and definitions, see the Data Appendix. Automobile Industry only includes caravans and trucks.

*: Some firms may belong to multiple branches. 
Table 2

Summary Statistics for Firms

Number of Elementary Products per Firm

\begin{tabular}{|c|c|c|c|c|}
\hline & $\begin{array}{c}\text { Median } \\
\text { (number) }\end{array}$ & $\begin{array}{c}\text { First Quartile } \\
\text { (number) }\end{array}$ & $\begin{array}{c}\text { Third Quartile } \\
\text { (number) }\end{array}$ & $\begin{array}{c}\text { Maximum } \\
\text { (number) }\end{array}$ \\
\hline \multicolumn{5}{|l|}{ Intermediate Goods } \\
\hline Refined Petroleum Products & 14 & 8 & 18 & 20 \\
\hline Basic Steel Products & 3 & 2 & 5 & 6 \\
\hline Non Ferrous Metals & 2 & 2 & 3 & 8 \\
\hline Construction Materials & 3 & 2 & 6 & 19 \\
\hline Glass Industry & 3 & 3 & 4 & 6 \\
\hline Basic Chemicals & 3 & 2 & 8 & 20 \\
\hline Metallic Products & 5 & 2 & 7 & 16 \\
\hline Paper Industry & 2 & 2 & 4 & 19 \\
\hline Plastic and Rubber Industry & 3 & 2 & 6 & 36 \\
\hline \multicolumn{5}{|l|}{ Equipment Goods } \\
\hline Machinery Construction & 5 & 3 & 8.5 & 52 \\
\hline Electrical Equipment & 5.5 & 3.5 & 9 & 44 \\
\hline Automobile Industry & 2 & 2 & 4 & 6 \\
\hline \multicolumn{5}{|l|}{ Consumption Goods } \\
\hline Parachemicals & 5 & 3 & 10 & 34 \\
\hline Textile and Clothing & 4 & 2 & 6 & 17 \\
\hline Wood and Furnishing & 4 & 3 & 8 & 47 \\
\hline
\end{tabular}

Notes : For sources and definitions, see the Data Appendix. Automobile Industry only includes caravans and trucks. 
Table 3

Summary Statistics for Firms

Number of Elementary Products per Basic Product

\begin{tabular}{|c|c|c|c|c|c|}
\hline & $\begin{array}{l}\text { Minimum } \\
\text { (number) }\end{array}$ & $\begin{array}{c}\text { First Quartile } \\
\text { (number) }\end{array}$ & $\begin{array}{c}\text { Median } \\
\text { (number) }\end{array}$ & $\begin{array}{c}\text { Third Quartile } \\
\text { (number) }\end{array}$ & $\begin{array}{c}\text { Maximum } \\
\text { (number) }\end{array}$ \\
\hline \multicolumn{6}{|l|}{ Intermediate Goods } \\
\hline Refined Petroleum Products & 3 & 4 & 5.5 & 8 & 9 \\
\hline Basic Steel Products & 2 & 3 & 3 & 4.5 & 6 \\
\hline Non Ferrous Metals & 2 & 3 & 3 & 4 & 4 \\
\hline Construction Materials & 2 & 2 & 3 & 6.5 & 17 \\
\hline Glass Industry & 2 & 3 & 4.5 & 5 & 6 \\
\hline Basic Chemicals & 2 & 2 & 3 & 5 & 27 \\
\hline Metallic Products & 2 & 3 & 4 & 7 & 13 \\
\hline Paper Industry & 2 & 3 & 4 & 5 & 18 \\
\hline Plastic and Rubber Industry & 2 & 3 & 4 & 7 & 23 \\
\hline \multicolumn{6}{|l|}{ Equipment Goods } \\
\hline Machinery Construction & 2 & 2 & 4 & 6 & 33 \\
\hline Electrical Equipment & 2 & 3 & 4 & 7 & 24 \\
\hline Automobile Industry & 2 & 2.5 & 3 & 3.5 & 4 \\
\hline \multicolumn{6}{|l|}{ Consumption Goods } \\
\hline Parachemicals & 2 & 3 & 4 & 6.5 & 13 \\
\hline Textile and Clothing & 2 & 2 & 4 & 6 & 16 \\
\hline Wood and Furnishing & 2 & 3 & 5 & 7.5 & 26 \\
\hline
\end{tabular}

Notes : For sources and definitions, see the Data Appendix. Automobile Industry only includes caravans and trucks. 
Table 4

Summary Statistics for Firms

Price Evolution Indices, all years together (Elementary Products)

\begin{tabular}{|c|c|c|c|c|c|}
\hline & $\begin{array}{l}\text { Minimum } \\
\text { (index) }\end{array}$ & $\begin{array}{c}\text { First Quartile } \\
\text { (index) }\end{array}$ & $\begin{array}{l}\text { Median } \\
\text { (index) }\end{array}$ & $\begin{array}{l}\text { Third Quartile } \\
\text { (index) }\end{array}$ & $\begin{array}{l}\text { Maximum } \\
\text { (index) }\end{array}$ \\
\hline \multicolumn{6}{|l|}{ Intermediate Goods } \\
\hline Refined Petroleum Products & 0.99 & 1.00 & 1.00 & 1.02 & 1.07 \\
\hline Basic Steel Products & 0.97 & 0.98 & 1.02 & 1.11 & 4.78 \\
\hline Non Ferrous Metals & 0.97 & 0.98 & 1.00 & 1.00 & 1.06 \\
\hline Construction Materials & 0.75 & 0.97 & 1.00 & 1.02 & 1.16 \\
\hline Glass Industry & 0.93 & 0.96 & 0.99 & 1.01 & 1.03 \\
\hline Basic Chemicals & 0.79 & 0.96 & 1.00 & 1.05 & 3.44 \\
\hline Metallic Products & 0.82 & 0.95 & 1.00 & 1.04 & 2.12 \\
\hline Paper Industry & 0.92 & 0.98 & 1.01 & 1.02 & 1.07 \\
\hline Plastic and Rubber Industry & 0.92 & 0.99 & 1.00 & 1.03 & 1.16 \\
\hline \multicolumn{6}{|l|}{ Equipment Goods } \\
\hline Machinery Construction & 0.65 & 0.98 & 1.00 & 1.02 & 1.17 \\
\hline Electrical Equipment & 0.56 & 0.96 & 1.00 & 1.02 & 1.67 \\
\hline Automobile Industry & 0.98 & 0.98 & 0.98 & 0.99 & 1.01 \\
\hline \multicolumn{6}{|l|}{ Consumption Goods } \\
\hline Parachemicals & 0.74 & 0.97 & 1.00 & 1.02 & 1.13 \\
\hline Textile and Clothing & 0.80 & 0.96 & 1.00 & 1.04 & 1.16 \\
\hline Wood and Furnishing & 0.81 & 0.97 & 1.00 & 1.02 & 1.22 \\
\hline
\end{tabular}

Notes : For sources and definitions, see the Data Appendix. Automobile Industry only includes caravans and trucks. 
Table 5

Summary Statistics for Firms

Annual Averages over the life of the firm (1978-1988)

\begin{tabular}{|l||c|c|c|c|}
\hline \hline Variable definition & Mean & Std Dev & Min & Max \\
\hline Average $x \beta$ of employees at the firm & 0.4064 & 0.0628 & 0.1070 & 0.6102 \\
Average $\alpha$ of employees at the firm & 0.0621 & 0.1663 & -0.5006 & 0.7263 \\
Average u $\eta$ of employees at the firm & 3.5606 & 0.0682 & 3.3272 & 4.0993 \\
$\phi$ Firm-specific wage premium & 0.0092 & 0.0841 & -0.5771 & 0.6390 \\
$\gamma 1$ Firm-specific seniority slope & -0.0028 & 0.0367 & -0.4642 & 0.3918 \\
$\gamma$ 2 Change in seniority slope at 10 years & -0.00003 & 0.0311 & -0.3297 & 0.5392 \\
Number of ind. observations sampled at firm & 442.3 & 1664.8 & 2 & 35776 \\
\hline Price Evolution (index) (N=4791) & 1.0018 & 0.0886 & 0.3486 & 4.4241 \\
Price Level (ratio) (N=4791) & 1.0091 & 0.7913 & 0.0003 & 12.932 \\
Number of Basic Products sampled at firm (Evolution) & 4.9182 & 2.8341 & 1 & 11 \\
Number of Basic Products sampled at firm (Level) & 7.5745 & 2.7073 & 1 & 15 \\
\hline Employment at December 31st (thousands) & 1.224 & 4.470 & 0.021 & 95.927 \\
Real total assets (millions FF 1980) & 522.7 & 2198.6 & 1.5 & 31653.6 \\
Operating Income/Total Assets & 0.1447 & 0.1203 & -0.4065 & 0.8592 \\
Valued-added/Total Assets & 0.7003 & 0.3237 & -0.0149 & 4.1706 \\
Real value added/Employee (thou. FF 1980) & 188.32 & 1094.9 & -11551.7 & 27512.2 \\
Real total assets/Employee (thou. FF 1980) & 3060.7 & 48495.3 & 41.4 & 1134643 \\
Employment (in logs): Average Growth & -0.0191 & 0.2553 & -4.4159 & 1.4828 \\
Assets (in logs): Average Growth & 0.0358 & 0.1360 & -1.4210 & 1.0724 \\
Sales (in logs): Average Growth & 0.0080 & 0.3813 & -7.1092 & 2.7940 \\
(Engineers, Professionals and Managers)/Employee & 0.2641 & 0.1388 & 0.0245 & 0.9423 \\
Skilled workers/Employee & 0.4364 & 0.1166 & 0.0502 & 0.7772 \\
Date of birth of firm (N=495) & 1965 & & 1954 & 1990 \\
Number of firms & 748 & & & \\
& & & & \\
\hline
\end{tabular}

Notes : For sources and definitions, see the Data Appendix. 
Table 6

Regression Results for Product Quality (Price Evolution Index) and

Worker Quality (Compensation Structure Measures)

\begin{tabular}{|c|c|c|}
\hline Independent Variables & $\begin{array}{c}\text { Summary } \\
\text { Statistics } \\
\text { (all firms) } \\
\text { (1) }\end{array}$ & $\begin{array}{l}\text { Price Evolution } \\
\text { Index } \\
\text { (all firms) } \\
\text { (2) }\end{array}$ \\
\hline Definition and symbol & $\begin{array}{l}\text { Means } \\
\text { (StD) }\end{array}$ & $\begin{array}{l}\text { Coeff. } \\
\text { (StE) }\end{array}$ \\
\hline Average individual effect $(\alpha)$ & $\begin{array}{c}0.0688 \\
(0.1684)\end{array}$ & $\begin{array}{c}0.0383 \\
(0.0175)\end{array}$ \\
\hline Average effect of time-varying observables $(x \beta)$ & $\begin{array}{c}0.4075 \\
(0.0592)\end{array}$ & $\begin{array}{c}0.0708 \\
(0.0368)\end{array}$ \\
\hline Average education effect $(u \eta)$ & $\begin{array}{c}3.5663 \\
(0.0698)\end{array}$ & $\begin{array}{l}-0.0963 \\
(0.0444)\end{array}$ \\
\hline Firm-specific intercept $(\phi)$ & $\begin{array}{c}0.0120 \\
(0.0756)\end{array}$ & $\begin{array}{c}-0.0939 \\
(0.0325)\end{array}$ \\
\hline Firm-specific seniority slope $\left(\gamma_{1}\right)$ & $\begin{array}{c}-0.0014 \\
(0.0382)\end{array}$ & $\begin{array}{l}-0.1423 \\
(0.0554)\end{array}$ \\
\hline Change in slope $\left(\gamma_{2}\right)$ & $\begin{array}{c}0.0009 \\
(0.0252)\end{array}$ & $\begin{array}{c}0.0444 \\
(0.0801)\end{array}$ \\
\hline (Engineers,Tech.,Managers)/Employee & $\begin{array}{c}0.2819 \\
(0.1512)\end{array}$ & $\begin{array}{c}0.0265 \\
(0.0276)\end{array}$ \\
\hline (Skilled Workers)/Employee & $\begin{array}{c}0.4214 \\
(0.1095)\end{array}$ & $\begin{array}{l}-0.0451 \\
(0.0245)\end{array}$ \\
\hline Log(Employment/Employment -1$)$ & $\begin{array}{c}0.7877 \\
(1.0198)\end{array}$ & $\begin{array}{c}0.0006 \\
(0.0017)\end{array}$ \\
\hline Log(Capital/Capital_-1) & $\begin{array}{c}0.8559 \\
(0.3591)\end{array}$ & $\begin{array}{l}-0.0019 \\
(0.0095)\end{array}$ \\
\hline Log(Sales/Sales_1 $)$ & $\begin{array}{c}0.8560 \\
(0.4244)\end{array}$ & $\begin{array}{c}0.0012 \\
(0.0080)\end{array}$ \\
\hline Number of Observations & 4791 & $\overline{4791}$ \\
\hline R-square & & 0.226 \\
\hline
\end{tabular}

Notes: The model - column (2) - was estimated using 4,791 observations for 748 firms with complete data. The regression includes 6 -digit basic product fixed effects. All estimates are corrected for the presence of estimated regressors (Pagan 1984). All sources are discussed in the Data Appendix. 
Table 7

Regression Results for Product Quality (Relative Price Level) and

Worker Quality (Compensation Structure Measures)

\begin{tabular}{|c|c|c|}
\hline Independent Variables & $\begin{array}{c}\text { Summary } \\
\text { Statistics } \\
\text { (all firms) } \\
(1) \\
\end{array}$ & $\begin{array}{c}\text { Relative Price } \\
\text { Level } \\
\text { (all firms) } \\
\text { (2) }\end{array}$ \\
\hline Definition and symbol & $\begin{array}{l}\text { Means } \\
\text { (StD) }\end{array}$ & $\begin{array}{l}\text { Coeff. } \\
(\mathrm{StE}) \\
\end{array}$ \\
\hline Average individual effect $(\alpha)$ & $\begin{array}{c}0.0688 \\
(0.1684)\end{array}$ & $\begin{array}{c}0.1311 \\
(0.1755)\end{array}$ \\
\hline Average effect of time-varying observables $(x \beta)$ & $\begin{array}{c}0.4075 \\
(0.0592)\end{array}$ & $\begin{array}{c}0.6140 \\
(0.3682)\end{array}$ \\
\hline Average education effect $(u \eta)$ & $\begin{array}{c}3.5663 \\
(0.0698)\end{array}$ & 0.8155 \\
\hline Firm-specific intercept $(\phi)$ & $\begin{array}{c}0.0120 \\
(0.0756)\end{array}$ & $\begin{array}{l}-0.3635 \\
(0.3246)\end{array}$ \\
\hline Firm-specific seniority slope $\left(\gamma_{1}\right)$ & $\begin{array}{c}-0.0014 \\
(0.0382)\end{array}$ & $\begin{array}{c}0.1133 \\
(0.5538)\end{array}$ \\
\hline Change in slope $\left(\gamma_{2}\right)$ & $\begin{array}{c}0.0009 \\
(0.0252)\end{array}$ & $\begin{array}{c}1.6655 \\
(0.8006)\end{array}$ \\
\hline (Engineers,Tech.,Managers)/Employee & $\begin{array}{c}0.2819 \\
(0.1512)\end{array}$ & $\begin{array}{c}0.7232 \\
(0.2757)\end{array}$ \\
\hline (Skilled Workers)/Employee & $\begin{array}{c}0.4214 \\
(0.1095)\end{array}$ & $\begin{array}{c}1.1221 \\
(0.2446)\end{array}$ \\
\hline Log(Employment/Employment $\left._{-1}\right)$ & $\begin{array}{c}0.7877 \\
(1.0198)\end{array}$ & $\begin{array}{c}0.0537 \\
(0.0176)\end{array}$ \\
\hline $\log _{\text {(Capital/Capital_-1) }}$ & $\begin{array}{c}0.8559 \\
(0.3591)\end{array}$ & $\begin{array}{c}0.0471 \\
(0.0950)\end{array}$ \\
\hline Log(Sales/Sales_1 $_{-1}$ & $\begin{array}{c}0.8560 \\
(0.4244)\end{array}$ & $\begin{array}{c}0.0059 \\
(0.0797)\end{array}$ \\
\hline Number of Observations & 4791 & 4791 \\
\hline R-square & & 0.022 \\
\hline
\end{tabular}

Notes: The model - column (2) - was estimated using 4,791 observations for 748 firms with complete data. The regression includes 6-digit basic product fixed effects. All estimates are corrected for the presence of estimated regressors (Pagan 1984). All sources are discussed in the Data Appendix. 
Table 8

Regression Results for Individual Wages

and

Product Quality (Existence of a Firm-Quality Norm)

\begin{tabular}{|l|c|c|}
\hline & Wage & Wage \\
& $\begin{array}{c}\text { Full Sample) } \\
(1)\end{array}$ & $\begin{array}{c}\text { (Matched Individual-Firm) } \\
(2)\end{array}$ \\
\hline & $\begin{array}{c}\text { Coeff. } \\
(\text { StE) }\end{array}$ & $\begin{array}{c}\text { Coeff. } \\
(\text { StE) }\end{array}$ \\
\hline Independent variables: & 0.0134 & 0.0080 \\
Existence of a Quality Norm & $(0.0069)$ & $(0.0076)$ \\
& & 3,682 \\
\hline Number of Observations & 15,909 & $-11,634.7$ \\
\hline Log-Likelihood & $-31,967.1$ & \\
\hline
\end{tabular}

Notes: The dependent variable (wage) has a discrete structure with bandwidths of $500 \mathrm{FF}$ for low wages, $1000 \mathrm{FF}$ for intermediate wages, $5000 \mathrm{FF}$ for high wages. The estimation technique accounts for the structure of this variable. The model in column (1) was estimated using 15,909 individual observations. The model in column (2) was estimated using 3,682 observations for the individuals that could be matched with their firms. Both models control for New Technologies variables, experience with NT, tenure, experience, education, sex, hours of work, marital status, region of work, working schedules, occupation and 2digit sector dummies. Furthermore, column (1) includes firm-size dummies and column (2) controls for the employees' firm skill-structure (share of engineers, professionals and technicians and share of skilled workers in total employment), assets (log), total employment (log), export ratio and profit ratio (real operating margins/assets). All sources are discussed in the Data Appendix and in the text. 


\section{Appendix B}

Titles of Elementary Products and Basic Products

(Examples)

\begin{tabular}{|c|c|c|}
\hline Firm & $\begin{array}{l}\text { Basic Product } \\
\text { (in French) }\end{array}$ & $\begin{array}{l}\text { Firm's Title of the Elementary Product } \\
\text { (in French) }\end{array}$ \\
\hline $\begin{array}{l}1 \text { (Basic Chemicals) } \\
1 \text { (Basic Chemicals) } \\
1 \text { (Basic Chemicals) } \\
1 \text { (Basic Chemicals) } \\
1 \text { (Basic Chemicals) } \\
2 \text { (Basic Chemicals) } \\
2 \text { (Basic Chemicals) } \\
2 \text { (Basic Chemicals) } \\
2 \text { (Basic Chemicals) } \\
2 \text { (Basic Chemicals) }\end{array}$ & $\begin{array}{l}\text { Butadiène, Butylène et dérivés } \\
\text { Butadiène, Butylène et dérivés } \\
\text { Butadiène, Butylène et dérivés } \\
\text { Alkyl-Benzène et dérivés } \\
\text { Dérivés du Propylène } \\
\text { Alkyl-Benzène et dérivés } \\
\text { Alkyl-Benzène et dérivés } \\
\text { Dérivés du Propylène } \\
\text { Ethanol, Ac. Acétique et dérivés } \\
\text { Ethanol, Ac. Acétique et dérivés }\end{array}$ & $\begin{array}{l}\text { Butadiène } \\
\text { Methyl-ethyl-cétone } \\
\text { Phtalate } 7-11 \\
\text { Acétone D.M.K. } \\
\text { Alcool Isopropylique I.P.A. } \\
\text { Acétone code } 23412 \\
\text { Phénol C } 40 / 41 \text { code } 55294 \\
\text { Oxyde de Propylène code } 26486 \\
\text { Acide Acétique code } 12127 \\
\text { Acétate de Vinyle Monomère code } 13564\end{array}$ \\
\hline $\begin{array}{l}3 \text { (Textile) } \\
3 \text { (Textile) } \\
3 \text { (Textile) } \\
4 \text { (Textile) } \\
4 \text { (Textile) }\end{array}$ & $\begin{array}{l}\text { Fil Cardé Classique Teint pour Bonneterie } \\
\text { Fil Cardé Classique Teint pour Bonneterie } \\
\text { Fil Ecru Cardé Classique pour Tissage } \\
\text { Fil Cardé Classique Teint pour Bonneterie } \\
\text { Fil Ecru Cardé Classique pour Tissage }\end{array}$ & $\begin{array}{l}\text { Ambiance, NM } 1 / 37 \text { fixe } \\
\text { brillant,fil teint néochrome acrylique } 100 \% \text { fibre courte } \\
\text { Fil Brillant, Néochrome NM } 1 / 30 \\
\text { teint en bourre coloris marine coton acrylique } 50-50 \\
\text { Elvira CS polyester } \\
100 \% \text { non feu, NM } 2 / 40 \text { retors } \\
\text { Qualité Corrèze, } \\
\text { NM } 1 / 40 \text { coton acrylique } 50-50 \\
\text { Qualité Béarn, } \\
\text { NM } 2 / 34 \text { pur acrylique }\end{array}$ \\
\hline
\end{tabular}

